Przegląd Prawa Konstytucyjnego

----ISSN 2082-1212-----

DOI 10.15804/ppk.2018.03.10

-----Nr $3(43) / 2018-----$

\title{
Wspomnienie o Panu Profesorze Eugeniuszu Zwierzchowskim
}

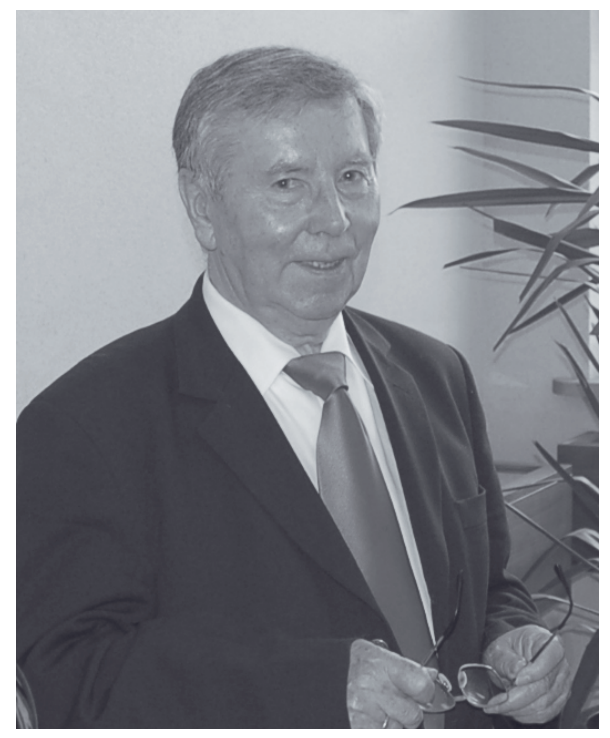

Profesor Eugeniusz Zwierzchowski zmarł 15 marca 2018 r. Urodzony 10 lipca 1929 r. w Grójcu niemal całe dorosłe życie spędził na Górnym Śląsku. Po drodze była wojna i być może lata jeszcze trudniejsze i także trudniejsze wybory. O powojennych losach Profesor mówił dopiero na emeryturze. Ja usłyszałam o nich znacznie wcześniej, od jednego z moich starszych kolegów, ale wtedy takie fakty opisywano nieczęsto i niedokładnie. W latach 1948-1949 Profesor odbywał karę pozbawienia wolności za „działalność na rzecz Niepodległego bytu Państwa Polskiego”, w więzieniu mokotowskim w Warszawie.

Profesora E. Zwierzchowskiego poznałam już po zakończeniu moich studiów prawniczych. Był pracownikiem naukowym Katedry Prawa Konstytucyjnego na Wydziale Prawa Uniwersytetu Śląskiego od 1 października 1968 r., ale w „moich czasach” nie prowadził wykładu. Miał opinię bardzo surowego 
egzaminatora, więc cieszyliśmy się, że jest szansa uniknięcia „trudnej konfrontacji”. Wiele lat później, już jako adiunkt w Katedrze przekonałam się, że Profesor rzeczywiście zadawał czasem pytania niełatwe. Wraz z moim kolegą z Katedry nie potrafiliśmy nawet wyjaśnić studentom, co należało odpowiedzieć na jedno z pytań zadanych na egzaminie. A przecież nie mogliśmy pójść do Profesora z naszym „problemem”. Na wykłady prowadzone przez Profesora, zgodnie z obyczajem, chodziłam dopiero jako Jego asystentka.

Profesor przyjechał do Katowic z Wydziału Prawa Uniwersytetu Jagiellońskiego, gdzie w 1956 r. ukończył studia prawnicze, a następnie rozpoczął pracę naukową w Katedrze Prawa Państwowego pod kierunkiem Profesora Konstantego Grzybowskiego. W okresie krakowskim prowadził badania przede wszystkim w dziedzinie ustroju II Rzeczypospolitej, które podsumował doktoratem obronionym w 1966 r. Promotorem rozprawy był ostatecznie Profesor Witold Zakrzewski, który objął Katedrę po przedwczesnej śmierci Profesora Konstantego Grzybowskiego. Tematem rozprawy było Stanowisko głowy państwa w polskich projektach konstytucyjnych lat 1928-1935.

Profesor nie wrócił już do spraw ustroju II RP, w każdym razie w tej dziedzinie już nie publikował, ale zainteresowanie zakresem władzy jednostki i generalnie pozycją władzy wykonawczej uwidoczniło się w Jego badaniach nad ustrojem Niemiec po II wojnie światowej. Był to efekt nie tylko zainteresowań. Profesor zaangażował się w problematykę niemiecką także dlatego, by podjąć badania w dziedzinie nie poddanej takim ograniczeniom politycznym, jakim poddawano w tym czasie badania dotyczące ustroju Polski.

Owocem tej działalności była monografia stanowiąca rozprawę habilitacyjną na temat Prawnoustrojowe stanowisko kanclerza NRF, która stała się podstawą nadania w 1972 r. przez Radę Wydziału Prawa i Administracji Uniwersytetu Jagiellońskiego stopnia naukowego doktora habilitowanego. W tym czasie Profesor Zwierzchowski był już docentem i na tym stanowisku pozostawał do $1986 \mathrm{r}$. kiedy to na podstawie dorobku naukowego otrzymał tytuł naukowy profesora.

Przedmiotem badań naukowych prowadzonych przez Profesora były nie tylko zagadnienia kształtującego się ustroju Polski z czasów Międzywojnia oraz Niemiec, ale również teoria prawa konstytucyjnego. Profesor należał do tych pokoleń polskich uczonych, dla których zagadnienia ustrojowe miały zawsze kontekst historyczny, a ich właściwe opracowanie nie było możliwe bez wskazania źródeł doktrynalnych. Dało się to nieraz zauważyć nawet w krótkich rozmowach, które czasami prowa- 
dziliśmy. Te nasze rozważania zawsze podbudowane były także gruntowną wiedzą teoretyczną. Zapewne dlatego tak chętnie wracam do niewielkiej rozmiarami, ale jakże ważnej monografii Profesora wydanej w Katowicach, w 1992 r. „Wprowadzenie do nauki prawa konstytucyjnego państw demokratycznych" to przykład takiego rozumienia nauki. Nadal z tej pracy korzystamy i zachęcamy do tego studentów.

W latach 80. XX w. Profesor poszerzył Swoje badania o zagadnienia, które w kolejnych dziesięcioleciach miały dla Polski szczególne znaczenie. Przede wszystkim chodzi o sądownictwo konstytucyjne, ale także zagadnienia współczesnego parlamentaryzmu. Opublikował tak ważne monografie, jak: Europejskie trybunaty konstytucyjne (1989 r.) i Sądownictwo konstytucyjne (1994 r.). Ukazały się także dwie prace zbiorowe redagowane przez Profesora, a mianowicie: Izby drugie parlamentu (1996 r.) i Status opozycji parlamentarnej (2000 r., red. wspólnie z S. Bożykiem).

Już będąc profesorem emerytowanym powrócił do publikacji w sprawach niemieckich. Świetna znajomość tej tematyki uwieńczona została artykułem Rząd w systemie parlamentarnym RFN opublikowanym w „Przeglądzie Sejmowym” poświęconym 60-leciu uchwalenia konstytucji RFN (2009, nr 10).

W 1987 r. Profesor nawiązał wieloletnią współpracę z Filią Uniwersytetu Warszawskiego w Białymstoku, którą następnie kontynuował po jej przekształceniu w samodzielny Uniwersytet. Przez wiele lat kierował tamtejszą Katedrą Prawa Konstytucyjnego.

Profesor Zwierzchowski zasłużył się także społeczności akademickiej pełniąc różne funkcje. W roku akademickim 1972/1973 był dziekanem Wydziału Prawa i Administracji Uniwersytetu Śląskiego. W latach 1973-1978, przez dwie kadencje piastował funkcję prorektora Uniwersytetu Śląskiego. Był wieloletnim kierownikiem Katedry Prawa Konstytucyjnego Wydziału Prawa i Administracji Uniwersytetu Śląskiego.

Profesor Zwierzchowski był przez dwie kadencje członkiem Komitetu Nauk Prawnych PAN, a w latach 1990-1992 członkiem Zespołu Prawa Konstytucyjnego Rady Legislacyjnej przy Prezesie Rady Ministrów.

Profesor Eugeniusz Zwierzchowski był odznaczony Krzyżem Kawalerskim, Oficerskim i Komandorskim Orderu Odrodzenia Polski.

Cześć Jego pamięci. 
Pana Profesora Eugeniusza Zwierzchowskiego nie ma już pośród nas, jednak nieustannie pozostaje obecny w pamięci Swych przyjaciół, koleżanek, kolegów oraz uczniów. Wyrazem tej obecności są wspomnienia o Profesorze przygotowane przez przedstawicieli nauki prawa konstytucyjnego, osoby, które pozostawały z Nim w bliskich relacjach. Oto niektóre z nich:

\section{Wspomnienie Profesora Stanisława Bożyka}

Pana Profesora Eugeniusza Zwierzchowskiego poznałem bliżej dopiero w 1988 r. Pamiętam, że było to podczas mroźnej i niezwykle śnieżnej zimy. Pan Profesor przyjechał do Białegostoku, aby ustalić szczegóły swojego dodatkowego zatrudnienia, wtedy jeszcze na Filii UW w Białymstoku. Uczestniczyłem wówczas w spotkaniu Profesora z ówczesnym dziekanem Prof. E. Smoktunowiczem oraz we wspólnym obiedzie. Odwiozłem wreszcie Pana Profesora na dworzec PKP. Patrząc na ośnieżone ulice Białegostoku, Profesor stwierdził, że Białystok mu się bardzo podoba, że jest tu niesamowicie czyste powietrze i chyba zdecyduje się na pracę na Podlasiu. Tak się też stało i w konsekwencji Prof. Zwierzchowski dojeżdżał z Katowic na zajęcia do Białegostoku przez 17 lat (1988-2005).

W okresie zatrudnienia Pana Profesora w Białymstoku zostałem Jego najbliższym współpracownikiem, zarówno w sferze organizacyjnej, jak też naukowej i dydaktycznej. Do tego doszły oczywiście bardzo częste i intensywne kontakty osobiste, można powiedzieć, że wręcz przyjacielskie. Profesor był człowiekiem niezwykle życzliwym, można było zawsze liczyć na Jego pomoc i cenne rady. Takim też pozostanie w mojej pamięci.

Prof. Eugeniusz Zwierzchowski przyjeżdżał do Białegostoku co dwa tygodnie. Na czas swojej nieobecności upoważnił mnie do podejmowania, za Jego zgodą, wszelkich bieżących decyzji dotyczących Katedry Prawa Konstytucyjnego. Tym samym mogłem przygotować się u boku Mistrza do pełnienia powierzonej mi później funkcji kierownika Katedry.

W czerwcu 1995 r. Pan Profesor zorganizował Zjazd Katedr w Białowieży. Był niezwykle zaangażowany w przygotowania do Zjazdu, a my, młodsi pracownicy Katedry, wspieraliśmy jego działania. Potem Profesor wyrażał głośno swoje zadowolenie, że Zjazd ten był bardzo udany. Cie- 
szył się przy tym, że uczestników Zjazdu w Białowieży odwiedził przewodniczący Komisji Konstytucyjnej Zgromadzenia Narodowego Aleksander Kwaśniewski.

Niezwykle cenna była dla mnie wszechstronna współpraca naukowa z Panem Profesorem. Był On zazwyczaj pierwszym czytelnikiem moich publikacji przygotowanych do druku, dzięki Jego inspiracji na dłużej zainteresowałem się badaniami statusu prawnoustrojowego opozycji parlamentarnej w Polsce i w innych systemach ustrojowych. Wspierałem aktywnie Pana Profesora podczas przygotowywania do druku dwóch opracowań zbiorowych pod Jego redakcją naukową. Pierwszym z nich były Izby drugie parlamentu, drugim zaś Opozycja parlamentarna.

Moja współpraca dydaktyczna z Panem Profesorem sprowadzała się w głównej mierze do „kooperacji” przy promowaniu magistrantów. Ja byłem recenzentem praktycznie wszystkich prac magisterskich, które pod kierunkiem Profesora przygotowywali studenci stacjonarnego prawa. Pan Profesor z kolei był niejednokrotnie recenzentem prac moich magistrantów ze studiów niestacjonarnych. Poza tym każdego roku pomagałem Profesorowi w egzaminowaniu studentów z prawa konstytucyjnego. Tutaj warto chyba podkreślić, że prof. E. Zwierzchowski preferował wyłącznie egzamin ustny i był pod tym względem bardzo konsekwentny. Mogę tylko dodać, że do dziś kontynuuję tę regułę Profesora, gdyż w formie ustnej przeprowadzam wszystkie egzaminy.

Po przejściu Pana Profesora na emeryturę utrzymywałem z Nim stałą korespondencję, zasięgałem niejednokrotnie Jego rad i opinii, informowałem Go o swoich małych sukcesach. Profesor zawsze bardzo szybko odpowiadał na moje listy. Ostatni otrzymałem kilka miesięcy temu wraz z życzeniami na święta Bożego Narodzenia.

\section{Wspomnienie Profesora Adama Jamroza}

Wraz z odejściem profesora Eugeniusza Zwierzchowskiego - polskie ustrojoznawstwa utraciło jednego ze swych wybitnych reprezentantów.

Nieprzypadkowo piszę, że był ustrojoznawcą. Inaczej bowiem niż obecnie wielu przedstawicieli prawa konstytucyjnego, zajmował się nie tylko pra- 
wem konstytucyjnym „sensu stricto” (zwłaszcza obowiązującym), ale także innymi elementami ustrojoznawstwa: zasadami ustrojoznawstwa, systemami rządów państw demokratycznych oraz szerzej - zasadami funkcjonowania ustrojów demokratycznych. Nie chcę bliżej przywoływać tych prac, bowiem są one powszechnie znane (powinny być!) w literaturze ustrojoznawczej. Jego wkład do teorii ustrojoznawstwa demokratycznego (obszar dzisiaj coraz rzadziej eksploatowany) jest więc istotny.

Był uczonym trzech uniwersytetów. Najpierw - Uniwersytetu Jagiellońskiego, gdzie Jego mistrzem był prof. Witold Zakrzewski, gdzie obronił w $1966 \mathrm{r}$. doktorat. Tam też zetknąłem się z Nim po raz pierwszy jako student Wydziału Prawa. Od 1968 r. pracował na Wydziale Prawa Uniwersytetu Śląskiego, gdzie później kierował Katedrą Prawa Konstytucyjnego. Pełnił również na tym Wydziale funkcje dziekana, a następnie prorektora Uniwersytetu Śląskiego. Wówczas miałem okazję lepiej poznać Eugeniusza, bo również przeniosłem się do Uniwersytetu Śląskiego.

Trzeci z Uniwersytetów prof. Zwierzchowskiego - to Uniwersytet w Białymstoku (najpierw - Filia Uniwersytetu Warszawskiego w Białymstoku). Rozpoczął tutaj pracę na Wydziale Prawa 1 października 1988 r.; pracował do 30 września 2005 r. Był kierownikiem Katedry Ustrojoznawstwa, a później Katedry Prawa Konstytucyjnego. W okresie swojej pracy wypromował ponad 100 magistrów prawa i kilku doktorów, był opiekunem dwóch habilitantów. Był dla swoich pracowników mistrzem i autorytetem.

W okresie pracy w Uniwersytecie w Białymstoku Profesor poszerzył swe zainteresowania naukowe w licznych publikacjach, zwłaszcza w sferze parlamentaryzmu i sądownictwa konstytucyjnego. Niektóre z monografii tego okresu zostały wydane przez wydziałowe wydawnictwo Temida 2 (np. Sadownictwa konstytucyjne, 1994).

Bez przesady mogę stwierdzić, że prof. Eugeniusz Zwierzchowski wniósł znaczący wkład w rozwój Wydziału Prawa Uniwersytetu. Stwierdzam to nie tylko z moralnego obowiązku jako były Dziekan Wydziału i były Rektor Uniwersytetu w Białymstoku. Także jako Jego przyjaciel, który dostrzegał w Nim człowieka przyjaznego wszystkim, prawego i sprawiedliwego. 


\section{Wspomnienie Profesora Jerzego Jaskierni}

Profesor Eugeniusz Zwierzchowski był jedną z tych postaci prawa konstytucyjnego, z którą miałem się okazję zetknąć się jeszcze w okresie studenckim, a także jako młody naukowiec Uniwersytetu Jagiellońskiego w Krakowie. Należał bowiem do grona najwybitniejszych konstytucjonalistów, związanych w tym czasie z krakowską Alma Mater. Byli wśród nich: Konstanty Grzybowski, Witold Zakrzewski i Marek Sobolewski. Nie współpracowałem z nim bezpośrednio, gdyż gdy ja zaczynałem karierę naukową na UJ, prof. E. Zwierzchowski już przeszedł na Uniwersytet Śląski, który powstał na bazie filii UJK. Z dużym zainteresowaniem śledziłem jednak jego prace naukowe, zwłaszcza dotyczące Republiki Federalnej Niemiec. Był jednym z tych, którzy zainspirowali mnie do podjęcia zagadnień federalizmu, czego wyrazem była moja dysertacja doktorska „Pozycja stanów w systemie federalnym USA i zagadnie nie ich roli w realizacji zadań państwa”.

Nigdy nie zapomnę dysput toczonych z Profesorem podczas spacerów w trakcie corocznych Zjazdów Katedr i Zakładów Prawa Konstytucyjnego. Zwłaszcza pamiętam ten w Wiśle, w dniach 3-5 czerwca 1999 r., gdzie E. Zwierzchowski z wielkim kunsztem przewodniczył obradom plenarnym. Po zakończeniu dyskusji zwrócił się do referentów: „Zostawcie coś dla nas”. Chodziło mu o to, by referenci, oddając referaty do druku, nie uwzględniali argumentów wysuniętych przez uczestników dyskusji, by ci ostatni mieli też swój wkład do dorobku zjazdu, gdy opublikowana zostanie książka pokonferencyjna.

Właśnie podczas tego zjazdu E. Zwierzchowski poinformował, że pracuje nad pracą zbiorową dotyczącą opozycji. Zwrócił się do uczestników zjazdu o udział. Podjąłem to zaproszenie i efektem tego był mój tekst Opozycja parlamentarna w świetle standardów Rady Europy, zamieszczony w książce pod redakcją E. Zwierzchowskiego pt. Opozycja parlamentarna, (Wydawnictwo Sejmowe, Warszawa 2000).

Profesor Eugeniusz Zwierzchowski pozostanie w mojej pamięci jako człowiek wielkiej rozwagi i wyważonych poglądów, przyjazny dla rozwoju młodej kadry naukowej i chętnie dzielący się z nią swymi doświadczeniami życiowymi, nie zawężonymi do spraw naukowych. 


\section{Wspomnienie Profesora Grzegorza Kryszenia}

Pomimo upływu z górą trzydziestu lat stale mam w pamięci przebieg mojego spotkania z Panem Profesorem Eugeniuszem Zwierzchowskim, które zainaugurowało naszą znajomość, a nawet zażyłość. Doszło do niego przy okazji Jego rekonesansowego przyjazdu do Białegostoku, którego efektem było podjęcie pracy w ówczesnym Instytucie Prawa Filii Uniwersytetu Warszawskiego w Białymstoku, przekształconym wkrótce w Wydział Prawa tej uczelni, a następnie - w 1997 r. - Uniwersytetu w Białymstoku; początkowo w charakterze kierownika Zakładu Prawa Konstytucyjnego, a później Katedry Prawa Konstytucyjnego. Podkreślić wypada, iż wizyty w Białymstoku, który bardzo polubił, i prowadzone w tym mieście zajęcia ze studentami sprawiały Panu Profesorowi wyraźną przyjemność.

Z tego trwającego dwadzieścia lat okresu regularnych przyjazdów do Białegostoku na zawsze zapamiętam Pana Profesora jako osobę godną najwyższego szacunku, będącą dla mnie ogromnym autorytetem nie tylko w sprawach naukowych. Pobyty te stwarzały sposobność do wielowątkowych rozmów, bardzo często wykraczających poza sferę naukową. Ze szczególną nostalgią wspominam te, które miały miejsce podczas spacerów po zakończonych przez Pana Profesora zajęciach na Wydziale Prawa do miejsca zakwaterowania - przez białostockie Planty i fragment Lasu Zwierzynieckiego.

Profesor Eugeniusz Zwierzchowski był erudytą, jego niezwykle bogaty zasób wiedzy i zainteresowań wręcz onieśmielał. Nie narzucał jednak swego stanowiska, nawet wówczas, gdy w określonej kwestii było ono bezkompromisowe. Jego wypowiedzi cechowało poczucie odpowiedzialności za słowo. W dziedzinie prawa konstytucyjnego często dostrzegał to, czego ja nie byłem w stanie zauważyć. Oryginalne, inspirujące mnie, były interpretacje Pana Profesora różnorodnych problemów konstytucyjnych. Jestem ogromnie wdzięczny Jemu zwłaszcza za cenne uwagi odnoszące do przygotowywanej przeze mnie rozprawy habilitacyjnej.

Co jest przy tym niezmiernie ważne, Pan Profesor nie uległ „przypadłości” części uczonych, dla których jedynym lub zdecydowanie wiodącym bytem jest sfera nauki, zasklepianie się w niej, zaś wszystkie inne są traktowane jako marginalne, podrzędne. Potrafił w tym zakresie utrzymywać właściwe proporcje. 
Profesor Eugeniusz Zwierzchowski był otwarty na „ludzkie sprawy” i w razie potrzeby pomocny w ich rozwiązywaniu. Sam doświadczyłem wiele razy Jego życzliwości. Na zawsze zachowam w pamięci m.in. wielce dobroczynny wpływ, jaki wywarła na mnie wizyta Pana Profesora w szpitalu, gdy przeżywałem bardzo trudne chwile. Był po prostu mądrym, dobrym, przyzwoitym człowiekiem.

\section{Wspomnienie Profesora Zbigniewa Maciąga}

Już jako student drugiego roku studiów na Wydziale Prawa Uniwersytetu Jagiellońskiego (1963-1964) poznałem wówczas mgr Eugeniusza Zwierzchowskiego asystenta w Katedrze Prawa Państwowego, uczestniczącego też w seminariach prowadzonych przez profesorów Marka Sobolewskiego i Witolda Zakrzewskiego, a także w pracach koła naukowego. Niedługo po uzyskaniu przez Niego w 1966 r. stopnia doktora nauk prawnych przeszedł w 1968 r. do pracy w Uniwersytecie Śląskim, utworzonym na bazie dotychczasowej Filii UJ w Katowicach. Ja natomiast już jako asystent UJ podjąłem w tej Uczelni dodatkowe zajęcia dydaktyczne. W Katowicach zatem spotykaliśmy się dość często, zwłaszcza iż przedmiotem Jego zainteresowań była też problematyka ustrojowa Republiki Federalnej Niemiec. W pełni rozumiałem Jego zaangażowanie w rozwój Uniwersytetu Śląskiego, gdzie pełnił szereg funkcji, gdyż uważałem, podobnie jak on, że konieczny jest dynamiczny rozwój szkolnictwa wyższego, aby polska młodzież miała gdzie studiować. Dlatego też wspierając utworzenie Filii Uniwersytetu Warszawskiego w Białymstoku prowadziliśmy tam również zajęcia dydaktyczne z prawa konstytucyjnego.

Kiedy w 1988 r. zespół uczniów, współpracowników oraz kolegów Profesora Witolda Zakrzewskiego, pragnąc uczcić siedemdziesiątą rocznicę Jego urodzin, przygotowywał wydanie księgi jubileuszowej, Profesor E. Zwierzchowski zwrócił się do mnie, jako członek Komitetu Redakcyjnego tej księgi, z prośbą o przetłumaczenie złożonego również do niej artykułu prof. Rolfa Grawerta z Uniwersytetu w Bochum z języka niemieckiego na język polski. Zadanie to nie było łatwe, ale Prof. E. Zwierzchowski uważał to za pewien rodzaj uznania, a nawet zaszczytu dla mnie. Tak też zadanie to przyjąłem i wykonałem. W księdze tej ukazał się zatem nie tylko mój artykuł dedykowany 
Profesorowi Zakrzewskiemu, ale również moje tłumaczenie artykułu profesora R. Grawerta.

Profesora Eugeniusza Zwierzchowskiego zawsze wysoko ceniłem jako znawcę prawa konstytucyjnego, wspaniałego dydaktyka i organizatora struktur uniwersyteckich, z całym oddaniem służącego nauce polskiej. Jego odejście pozostanie dla nas wszystkich ogromną stratą. Nigdy Go nie zapomnimy.

\section{Wspomnienie Profesora Krzysztofa Skotnickiego}

Profesor Eugeniusz Zwierzchowski jest i pozostanie w mej pamięci osobą szczególną, gdyż był recenzentem w moim przewodzie doktorskim (drugim recenzentem był profesor Feliks Siemieński). A były to czasy, gdy recenzenci bezpośrednio przed obroną przed Radą Wydziału byli również egzaminatorami z przedmiotu. Nie muszę mówić, jak bardzo potęgowało to stres. I to w dużej mierze spokój Profesora, jak i jasne, precyzyjne pytanie oraz odczuwalna wyraźna życzliwość przyczyniły się do wyciszenia emocji. W dokumentach mam zachowaną sporządzoną przez Niego recenzję swojej dysertacji. Nie mam wątpliwości, że może ona służyć za wzór opracowywania takich opinii i była dla mnie wielce pomocna, gdy przyszło mi zmagać się z takim obowiązkiem po raz pierwszy.

W późniejszych latach z inicjatywy Profesora zmieniliśmy formę zwracania się do siebie, pisywaliśmy również do siebie tradycyjne listy.

Kiedy „Przegląd Sejmowy” obchodził dziesięciolecie istnienia, Profesor Eugeniusz Zwierzchowski już jako jeden z nestorów polskich konstytucjonalistów, zaś ja jako wówczas jeden najmłodszych doktorów habilitowanych w tym gronie, zostaliśmy poproszeni o ocenę tego periodyku i jej wygłoszenie podczas jubileuszowych uroczystości. Był to jedyny raz, kiedy występowaliśmy wspólnie, a dla mnie również szczególny zaszczyt, że pełnię tę rolę obok swojego recenzenta.

Chcąc przybliżyć we wspomnieniach osobę Profesora, przywołam jedną z naszych rozmów z czasu, gdy łączył pracę w Uniwersytecie Śląskim z kierowaniem Katedrą Prawa Konstytucyjnego Uniwersytetu w Białymstoku. Zapytałem, czy nie męczą go dojazdy. Dla pełnego oddania odpowiedzi należy przypomnieć, że Profesor mówił zawsze bardzo wolno i cicho. A była ona 
mniej więcej taka: „Ależ mój Drogi, to wcale nie jest męczące. O 6.05 ma pociąg z Katowic, który przyjeżdża do Warszawy przed 10.00. Tam się przesiadam i po dwudziestu minutach mam kolejny pociąg, który przyjeżdża do Białegostoku o 13.30, więc już o 14.00 rozpoczynam seminarium magisterskie”. Prawda, że proste i niemęczące?

\section{Wspomnienie Profesora Mariusza Jagielskiego}

Z Profesorem Eugeniuszem Zwierzchowskim pierwszy raz zetknąłem się na wykładach z prawa konstytucyjnego, które Profesor prowadził dla studentów II roku studiów prawniczych na Wydziale Prawa Uniwersytetu Śląskiego w Katowicach. Warto podkreślić, że Profesor był Autorem jednego z pierwszych (a może i pierwszego) podręcznika prawa konstytucyjnego napisanego po zmianach ustrojowych z 1989 r. (skryptu Wprowadzenie do nauki prawa konstytucyjnego państw demokratycznych wydanego w 1992 r.). W „zielonej książeczce” - jak nazywaliśmy ją jako studenci, ze względu na objętość i kolor okładki - dokonał Profesor tak znakomitej krytyki naukowej ustroju politycznego państw demokratycznych, że mimo iż formalnie była ona tylko skryptem dla studentów, to do dzisiaj jest przywoływana w poważnych opracowaniach naukowych.

Kilka lat później miałem zaszczyt stać się pracownikiem Katedry, której Profesor był Kierownikiem. Do dziś pamiętam spokój, rozwagę i szacunek, z jakim Profesor traktował swoich pracowników, także tych młodszych. Dla każdego, kto tylko chciał zwrócić się do Niego o radę, znajdował czas, z namysłem i uwagą podchodził do każdego zadanego pytania. Czasem oznaczało to długie chwile milczenia, ale potem odpowiedź padała - wyważona, głęboka, stanowiąca raczej podstawę do dalszych refleksji, niż wskazująca proste rozwiązanie problemu.

W podobny sposób Profesor podchodził także do studentów. Uważał, że każdemu należy dać szansę, że w każdym kryje się potencjał, który może być ujawniony. Pamiętam, jak zwrócił się do mnie jako do prowadzącego ćwiczenia z prawa konstytucyjnego na drugim roku studiów prawniczych, żebym przekazał moim studentom, że warto już teraz pomyśleć o doktoracie (sic!). Widząc moją zaskoczoną minę wyjaśnił: „wy, młodzi, nie zdajecie sobie sprawy z tego, że to właśnie teraz macie najwięcej czasu i zapału do pra- 
cy; potem tak już nie będzie”. Miał rację. Profesorowi nie podobała się moda, która zapanowała na polskich uczelniach w latach 90. na traktowanie studiów i studentów, jako źródła dochodów. Do historii przeszła wypowiedź Profesora z czasów, gdy pojawiały się pomysły zmniejszenia liczby godzin zajęciowych studentom niestacjonarnym. Podczas jednej z debat na ten temat, po wystąpieniu zwolennika takiego stanowiska, Profesor skonkludował z sarkazmem: „to może po prostu otwórzmy dwa okienka: w pierwszym będziemy przyjmować pieniądze, a w drugim wydawać dyplomy - to wszystko co pomiędzy jest niepotrzebne".

Na zawsze zostanie mi w pamięci obraz Profesora siedzącego na posiedzeniach Rady Wydziału obok profesora Maksymiliana Pazdana - dwóch szacownych akademików, naukowców „starej daty”, słuchających z uwagą toczącej się dyskusji. Rzadko zabierali głos, ale gdy któryś z nich to zrobił, to sala milkła. Siła Autorytetu.

\section{Wspomnienie Profesora Michała Bożka}

Lew Tołstoj często powtarzał, że wiedza daje pokorę wielkiemu, dziwi przeciętnego, a małego nadyma. Ilekroć myślę o zmarłym niedawno Profesorze Eugeniuszu Zwierzchowskim, tylekroć przed oczyma pojawia mi się postać człowieka pełnego mądrości i niezwykle wręcz skromnego. Nie była to przy tym mądrość mentora, odpornego na racje otoczenia, przekonanego o dogmatycznym charakterze swych poglądów, który niedostatek treści przykrywa nadmiarem formy. Była to mądrość żywa, dialogiczna, otwarta na drugiego człowieka jako na partnera, a nie przeciwnika czy podwładnego. Czerpał ją bowiem w pierwszym rzędzie z życia i całej gamy jego odcieni. Wiedział doskonale, że życie nie tyle ma wyraźne barwy, ile ledwie czasem dostrzegalne odcienie. Być może właśnie dlatego starał się nikogo nie pouczać, lecz skłonić do namysłu.

Bogactwem życiowych doświadczeń mógł był obdarować niejedną biografię. Nigdy jednak nie rościł sobie takich pretensji, a jeśli o doświadczeniach tych napominał, to zawsze $\mathrm{z}$ dystansem i niejako na marginesie głównego wątku rozmowy. A dystans względem Siebie potrafił zachować, jako mało kto. Pamiętam dobrze, gdy po wysłuchaniu peanów na Swój te- 
mat przy okazji uroczystości naukowego jubileuszu, siedział wyraźnie zawstydzony, zastanawiając się, co w takiej chwili wypada powiedzieć. Trafił wówczas w punkt, lakonicznie konstatując, że zazwyczaj podążał ścieżkami dobrze utartymi, toteż ów pochwalny hymn przyjmuje jako nie do końca zasłużony. Nie była to bynajmniej fałszywa skromność, kokietująca innych, a nade wszystko Siebie. Było to autentyczne wyznanie wiary człowieka przyjmującego świat po stoicku, świadomego własnych dokonań, przykładającego do nich jednak miarę właściwą człowiekowi znającemu wartość ludzkich wysiłków.

Lubił cytować słynną metaforę Kanta, że z pełnego gałęzi drzewa człowieczeństwa nie sposób wyciosać nic prostego. Metaforę tę twórczo zresztą rozwinął, sugerując mi niejednokrotnie, bym we wszystkim, co robię, kierował się dewizą - jak najlepszy efekt, jak najmniejszym nakładem sił. Umiar i zdrowy rozsądek to bowiem kolejne cechy, którymi Profesor emanował. Nader często wspierał je ogromnym poczuciem humoru, dzięki czemu rozmowa z Nim nawet o sprawach poważnych, przybierała lekką formę. Równie często Profesor lubił sprawy poważne ilustrować najróżniejszymi anegdotami. Z początku można było odnieść wrażenie, że rozmowa odbiega od tematu. Szybko jednak okazywało się, że opowiedziana anegdota to gotowe rozwiązanie problemu lub proste wyjaśnienie z pozoru skomplikowanego przypadku.

Niech więc wolno mi będzie zakończyć te słowa anegdotą jednego z Twoich ulubionych filozofów Profesorze, ks. Józefa Tischnera. Otóż podczas jednej z powodzi w Łopusznej chłopi stali przy moście na Dunajcu i obserwowali, co się dzieje, zastanawiając się czy wielka woda zabierze most, czy też nie. Nagle ich uwagę przykuło co innego, a mianowicie unoszący się na wodzie góralski kapelusz. Raz się zatrzymał, raz popłynął delikatnie z prądem. „Cóż to? Cud? - pyta jeden z chłopów. „E nie, to nie cud, ino Franek Gąsienica. Pedzioł, że ma gdzieś powódź i dalej orze”.

\section{Wspomnienie Profesora Krzysztofa Prokopa}

W annałach polskiej nauki prawa konstytucyjnego Profesor Eugeniusz Zwierzchowski jest i pozostanie wybitnym naukowcem, badaczem i pionierem szeregu kierunków naukowej eksploracji, wykonywanej przez większość Jego 
życia w trudnych latach peerelowskiej rzeczywistości. Dla mnie był, jest i pozostanie Pan Profesor osobistym Mistrzem i Nauczycielem, wzorcem naukowej doskonałości.

Moje najwcześniejsze wspomnienia z osobą Pana Profesora to Jego wykłady na pierwszym roku studiów białostockiego wydziału prawa (wtedy jeszcze będącego Filią Uniwersytetu Warszawskiego). Dwa lata później proseminarium, a następnie seminarium magisterskie. I początek wielkiej przygody. Olbrzymia wiedza z zakresu problemów naukowych, ale również i pamięć o wszystkich, których Profesor znał i pozwalał poznać od innej strony, niż ta, którą znamy z uczonych traktatów. No i konsultacje indywidualne. Zwykle w oparach (przynajmniej do czasu) tytoniowego dymu, który widocznie wspomagał potencjał twórczy.

Obrona pracy magisterskiej - chyba najbardziej stresujący egzamin w moim życiu, wliczając obronę doktoratu i kolokwium habilitacyjne (średnio udany egzamin na prawo jazdy zaliczam do innej kategorii). „Proszę Pana - mówi Profesor - tyle czasu rozmawialiśmy o Pańskiej pracy, że chyba nie ma sensu, żebym o cokolwiek Pana pytał”. Dostałem piątkę.

Moment przełomowy - przyjęcie na studia doktoranckie. Długi czas przygotowań do rozmowy na temat przyszłej dysertacji. Wspaniałe pomysły dwudziestopięcioletniego intelektu, mające zrewolucjonizować naukę. Tuż przed decydującą rozmową dopisany w autobusie, na kolanie, ostatni maleńki punkcik, jako wynik nerwowego wertowania konstytucji. Dwa słowa. Profesor skrytykował wszystko - poza tym punktem. Że za bardzo ambitne, że za mało, że ten temat byłby dobry, ale ktoś go w Polsce już pisze. Ten moment pozostanie ze mną już chyba do końca. „No dobrze - mówi Profesor napisze pan doktorat o stanach nadzwyczajnych". Wielkie nieba, cóż można napisać? Starszy kolega poradził mi, że może historycznie albo porównawczo. Może... Pół roku chodzenia za Profesorem. A gdyby tak coś innego? Tutaj jest taki ciekawy temat. Absolutnie, nie ma mowy. Zgroza. I siedem artykułów w konstytucji. Przez uchylone drzwi usłyszana rozmowa ze śp. Profesorem Zdzisławem Czeszejko-Sochackim, który podniesionym głosem przekonuje mojego Mistrza: „Stany nadzwyczajne, stany nadzwyczajne... Niech się zajmie czymś poważnym!”. I wprowadzenie do środowiska. „No..., to czekamy na komentarz" - mówi z przekąsem znany i uznany przedstawiciel świata polskich konstytucjonalistów. 
Taki był mój Profesor. Musiało być tak, jak postanowił. Nauczyłem się od Niego, by nigdy się nie poddawać, bronić do końca swojego zdania, jeśli tylko ma się do niego przekonanie. Poznałem proste i kręte ścieżki, jakimi może i jakimi musi - w określonych okolicznościach - podążać naukowiec. Od Profesora nauczyłem się szacunku dla wykonywanej pracy i odpowiedzialności za słowo. Poznałem różne uczucia towarzyszące procesowi twórczemu, zarówno ból, jak i radość. Mogłem dzięki mojemu Mistrzowi dowiedzieć się, że naukowiec nie może patrzeć obojętnie na zło tego świata, powinien krytycznie podchodzić do rzeczywistości, a zwłaszcza ganić i piętnować podłość, głupotę i wszelkiego rodzaju patologie, nieobce również światu akademickiemu.

Cóż, przecież nie obiecywał Pan, Panie Profesorze, że będzie lekko...

\section{Wspomnienie Profesora Krzysztofa Eckhardta}

Z Panem Profesorem Eugeniuszem Zwierzchowskim rozmawiałem zaledwie kilka razy w życiu i nie były to rozmowy zbyt długie. Zdecydowałem się napisać te kilka słów z innego powodu. Niemal dwadzieścia lat temu Pan Profesor był jednym $\mathrm{z}$ recenzentów mojego doktoratu. To w jaki sposób została napisana ta opinia do dzisiaj jest dla mnie wyznacznikiem wykonywania obowiązków recenzenckich i niedościgłym wzorem do naśladowania.

Jest wiele rzeczy za które jestem wdzięczny mojemu Mistrzowi Profesorowi Wiesławowi Skrzydle, jedną z nich jest to, iż zaproponował by właśnie Profesor Eugeniusz Zwierzchowski został recenzentem przygotowanego pod Jego kierunkiem doktoratu. Do tej pory nigdy o to nie zapytałem, ale jestem pewien, iż wiedział, że będzie to jeden z elementów „kształtowania” kolejnego z kilkudziesięciu swoich wychowanków naukowych.

Nie wiem czy potrafię właściwie oddać ten specyficzny styl recenzowania Pana Profesora Eugeniusza Zwierzchowskiego. Nie chodzi o to, iż była to recenzja wnikliwa merytorycznie, kompleksowa, pełna odniesień do ustaleń nie tylko polskiej nauki prawa konstytucyjnego i, co nie bez znaczenia, szybko napisana. To są walory oczywiste i właściwe dla całej pracy naukowej Pana Profesora. Chodzi raczej o sposób traktowania autora recenzowanej pracy. O połączenie krytycznej merytorycznej analizy z życzliwością, niekiedy zaprawioną lekką ironią. 
Rozpoczął Pan Profesor od przypomnienia, iż dzięki znakomitemu kierownictwu naukowemu Prof. Wiesława Skrzydły mogę zostać zaliczony do grona konstytucjonalistów prowadzących badania „, zakresu centralnej dla prawa konstytucyjnego państw demokratycznych problematyki relacji między władzą ustawodawczą i wykonawczą - w szczególności zaś - w odniesieniu do ich udziału w procesie stanowienia aktów prawnych".

Oczywiście stwierdzenie to, było dla mnie czymś niezwykle budującym, ale Recenzent nie pozwolił mi się wbić w bezkrytyczną dumę. Precyzyjne uwagi krytyczne Pan Profesor Zwierzchowski zwykł „osładzać” miłymi aczkolwiek „kąśliwymi” stwierdzeniami na przykład: „Taki oczytany i rozgarnięty autor, a nie..." albo „...zwracam na to uwagę ku przestrodze uzdolnionego autora...”.

Recenzent zachowywał także szczególny dystans do samego siebie pisząc miedzy innymi: „Ponieważ w innych ocenianych przeze mnie doktoratach bywało podobnie albo gorzej - o ile pamiętam w moim również - to widocznie na tym etapie naukowej twórczości trudno jest tego uniknąć”.

Ten nietuzinkowy, wolny od niepotrzebnego formalizmu i sztuczności sposób pisania opinii naukowych jest oczywiście niepowtarzalny ale może, i powinien, być wskazówką nie tylko dla uczniów Eugeniusza Zwierzchowskiego i osób, które miały przyjemność i zaszczyt spotkać Profesora na swej drodze zawodowej ale dla wszystkich którzy znajdą się w podobnej roli.

\section{Wspomnienie Profesor Sabiny Grabowskiej}

Informacja o śmierci Pana prof. Eugeniusza Zwierzchowskiego przyszła niespodziewanie. Znajomość z Panem Profesorem była dla mnie zaszczytem.

Pamiętam jak prawie dziesięć lat temu powstawało czasopismo „Przegląd Prawa Konstytucyjnego”. Pan Profesor był pierwszym recenzentem, zarówno samego pomysłu na czasopismo, jak i tekstów zgłoszonych do publikacji na jego łamach. Zgodził się bardzo chętnie i dzięki Jego uwagom czasopismo wiele zyskało. Jak napisał w recenzji: „Rękojmię powodzenia i rekomendację jakości przedsięwzięcia dają w tym wypadku zarówno ceniony ogólnopolski Wydawca, jak i zespół redakcyjny, kierowany przez prof. zw. dr. hab. Wiesława Skrzydłę, byłego wieloletniego Redaktora Naczelnego dwumiesięcznika „Przegląd Sejmowy”. U narodzin czasopisma można jedynie wyrazić prze- 
konanie, że „Przegląd Prawa Konstytucyjnego” stanie się trwałym dorobkiem polskiej nauki prawa konstytucyjnego, mówiąc nieco szerzej, wniesie istotny wkład do polskiej kultury prawnej. Życzę tego Wydawcy, inicjatorom i pierwszej Redakcji „Przeglądu Prawa Konstytucyjnego”. Jak dowiodły późniejsze lata - miał rację. Przegląd Prawa Konstytucyjnego znalazł uznanie i swoje miejsce w środowisku polskich i zagranicznych konstytucjonalistów. Co dowodzi, że Profesor umiał przewidzieć i właściwie ocenić nową inicjatywę i zachęcić dobrym słowem do działania.

Po odejściu Pana Profesora, mnie samej najbardziej będzie brakowało naszej wspólnej korespondencji listownej. Zawsze z okazji świąt i nie tylko, wysyłaliśmy do siebie życzenia i kilka słów o tym co się u nas zmieniło. Pan Profesor zawsze miał dla mnie dobre słowo. Teraz, gdy królują sms-y, taki tradycyjny list czy kartka zawsze rozczula i sprawia, że osoba otrzymująca taką korespondencje czuje się w taki sposób wyróżniona. Tak właśnie się czułam. A teraz niestety nigdy taka kratka już nie nadejdzie.

\section{Wspomnienie Profesora Andrzeja Bisztygi}

Pamiętam, że informacja o śmierci Profesora Zwierzchowskiego - długoletniego Kierownika Katedry Prawa Konstytucyjnego na Wydziale Prawa i Administracji Uniwersytetu Śląskiego zasmuciła mnie i wprawiła w nastrój nostalgiczny. Automatycznie pierwsze myśli - wspomnienia dotyczyły tego, że to Profesor w 1989 r. przyjmował mnie do pracy w Katedrze Prawa Konstytucyjnego WPiA UŚ, że był promotorem mojej rozprawy doktorskiej w 1996 r. oraz że był moim wieloletnim szefem. Od razu pragnę zaznaczyć, że był szefem dobrym, zapewne dlatego, że posiadał - co zwracało moją uwagę - umiejętności dialogowania, wyjaśniania, łagodnego perswadowania. Profesor nie „walczył” czy zarządzał swymi kolegami - podwładnymi, ale bardziej wskazywał, sugerował, zwracał się do nich z prośbą. Są to umiejętności i cechy czasem określane mianem miękkich kompetencji, które z pewnością służą konstytuowaniu się w miejscu pracy dobrej, koleżeńskiej atmosfery i klimatu sprzyjającego pracy naukowej, co miało istotne znaczenie dla właściwego funkcjonowania podległego mu zespołu badaczy. To, że Katedra Prawa Konstytucyjnego kierowana przez Profesora Eugeniusza Zwierzchowskiego odnosiła znaczące sukcesy naukowe, bra- 
ło swoje źródła między innymi w spolegliwym, dobrze pojętym akademickim stylu kierowania przez Niego tą Katedrą. Był gwarantem spokojnej współpracy i poczucia stabilności, jakże pożądanej w pracy naukowca. Profesor był osobą, którą po prostu dało się lubić i z którą z przyjemnością się pracowało. Pomimo dzielącej nas różnicy wieku i doświadczeń, Profesor nie dawał odczuć swych przewag, przeciwnie - w spokojnej rozmowie i dyskusji naprowadzał na nowe, warte podjęcia kierunki i zagadnienia badawcze, budząc zainteresowanie nimi, a nawet badawczy entuzjazm.

Spoglądam na mój dyplom doktorski, na którym widnieje nazwisko Pana Profesora jako promotora i wspominam dyskusje z Profesorem o systematyce i treściach mojej rozprawy doktorskiej. Pamiętam niektóre Jego techniczne, a zarazem zwyczajnie sympatyczne uwagi i wskazania. Podczas jednego z naszych seminariów uznał, że partie rozdziału dotyczące implementacji Konwencji Praw Człowieka w Republice Federalnej Niemiec są zbyt obszerne, więc wyjął z tego rozdziału plik kartek mówiąc: „a to będzie na artykuł”, czym poważnie odchudził wspomniany rozdział pracy. Natomiast już po napisaniu rozprawy, a przed jej złożeniem, Profesor polecił mi, bym jej maszynopis włożył na dwa tygodnie do szuflady i bym na ten czas o nim zapomniał. Rzeczywiście, po takim czasie odpoczynku od własnej pracy, czyta się ją w inny sposób, dostrzegając co można by ująć w niej lepiej, bądź w czytelniejszy dla odbiorcy sposób. Dzisiaj ja promując różne prace, sam z tej wskazówki Profesora Zwierzchowskiego korzystam.

Oczywiście, długo można by wymieniać dokonania i sukcesy Profesora w obszarach nauki i służby publicznej, one - co oczywiste - były i są, a z Jego prac, zwłaszcza z tych zawierających w sobie ładunek teoretycznoprawny, korzysta się i dzisiaj. Ale Profesora Zwierzchowskiego pamiętam - myślę, że nie jestem tu wyjątkiem - w pierwszej kolejności jako Człowieka i Naukowca, który swoim akademickim spokojem i życzliwą wobec współpracowników postawą sprawiał, że Uniwersytet rzeczywiście stawał się Alma Mater.

\section{Wspomnienie Doktora Lecha Jamroza}

Profesora zwyczajnego Eugeniusza Zwierzchowskiego wspominać będę jako wybitną postać nauki. Wielokrotnie mogłem się o tym przekonać bezpośred- 
nio, zwłaszcza jako Jego podopieczny na Wydziale Prawa Uniwersytetu w Białymstoku, gdyż Profesor był obecny na każdym etapie mojej edukacji prawniczej. Najpierw jako student pierwszego roku studiów prawniczych, kiedy uczęszczałem na wykłady prowadzone w ramach przedmiotu z prawa konstytucyjnego, później jako uczestnik seminarium magisterskiego (2002-2003).

Wspomniane tu pierwsze spotkania naukowe $\mathrm{z}$ Profesorem zaowocowały bliższym zainteresowaniem prawem konstytucyjnym i było to niewątpliwie Jego zasługą. Z inspiracji Profesora rozpocząłem studia doktoranckie, a swoje badania naukowe skupiłem na problematyce sądownictwa konstytucyjnego. W pamięci uczestników wskazanych wyżej zajęć (dziś w większości praktykujących prawników) oraz piszącego te słowa, Profesor dał się poznać jako profesjonalista, stanowiący wzór dla kolejnych pokoleń osób chcących rzetelnie realizować prawniczą profesję. Doświadczyliśmy Jego życzliwości, otwartości na potrzeby studentów, ale także stanowczości, która niewątpliwie przyczyniała się do utrzymania dyscypliny i wzmacniała efektywność zadań dydaktycznych i naukowych. Dziś to jeszcze bardziej doceniamy.

Jeśli można użyć względem osoby słów najbardziej pozytywnie wartościujących, to chciałbym to uczynić właśnie w odniesieniu do Profesora Eugeniusza Zwierzchowskiego. Tak, pozostanie dla mnie naukowym wzorem i autorytetem.

Profesor Eugeniusz Zwierzchowski odszedł z Naszego grona, nie uczynił tego jednak w sposób ostateczny i definitywny. Pozostał po Nim ogromny dorobek naukowy. To właśnie te dzieła stanowiące życiową spuściznę Profesora Zwierzchowskiego, jak również wspomnienia, które zachowaliśmy powodują, że Profesor Eugeniusz Zwierzchowski na zawsze pozostanie w pamięci swych bliskich, przyjaciół, uczniów i współpracowników.

Professor, non omnes mortuus! 